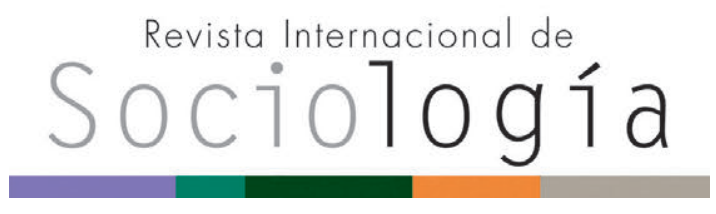

Revista Internacional de Sociología RIS vol. 74 (4), e045, octubre-diciembre, 2016, ISSN-L:0034-9712 doi: http://dx.doi.org/10.3989/ris.2016.74.4.045

\section{MECHANISMS OF SOCIAL MOVEMENT SUCCESS: Conversation, Displacement and Disruption}

\author{
ROBERT M. FISHMAN \\ Carlos III University, Madrid \\ robertmfishman@gmail.com \\ DAVID W. EVERSON \\ University of Notre Dame \\ deverson@nd.edu
}

Cómo citar este artículo / Citation: Fishman, R. M. and D. W. Everson. 2016. "Mechanisms of Social Movement Success: Conversation, Displacement and Disruption". Revista Internacional de Sociología 74 (4): e045. doi: http://dx.doi.org/10.3989/ris.2016.74.4.045

\begin{abstract}
A great deal of social movement scholarship tends to assume - and in some cases explicitly argues - that disruption is the primary mechanism through which protest movements win major concessions from the holders of power. Nonetheless, some studies and much empirical evidence provide a strong basis to argue that other paths to social movement success also exist. The importance of discourse and framing has also been highlighted in a number of studies but we argue that the full contribution of talk itself to movement success is best captured through the concept of "conversation" and an examination of the preconditions for its viability. The successful displacement of power-holders by protest movements, although a less common pathway to success than disruption and conversation, also deserves conceptual and empirical attention. In this paper we make this set of distinctions conceptually explicit, differentiating analytically between these three mechanisms of movement success and delineating the conditions required for each mechanism to prove viable and 'useful'. We rely on extensive examples drawn from movements and protest events in the United States, Spain and Portugal, using this empirical material, as well as the existing theoretical literature, as our basis for constructing a conceptual argument on the ideal typical distinction between these three mechanisms and the conditions that allow them to operate. We also take up the questions of whether, and when, movement actors can successfully combine these mechanisms or - alternatively find themselves pressed to pursue one or another of these pathways to success in a relatively 'pure' form.
\end{abstract}

\section{KEYWORDS}

Anti-austerity Protest; Discourse; Movement Outcome; Non-violent Protest; Protest.

\section{MECANISMOS PARA ENTENDER LOS LOGROS DE LOS MOVIMIENTOS: Conversación, desplazamiento y disrupción}

Copyright: (c) 2016 CSIC. This is an open-access article distributed under the terms of the Creative Commons Attribution License (CC BY) Spain 3.0.

\section{Received: 20/12/2015. Accepted: 01/07/2016. Published on line: 21/10/2016}

\section{Resumen}

Buena parte de la investigación en movimientos sociales tiende a asumir - y en algunos casos argumenta de manera explícita - que la disrupción es el principal mecanismo a través del cual los movimientos de protesta obtienen importantes concesiones por parte de quienes detentan el poder. No obstante, algunos estudios y mucha evidencia empírica proporcionan una base sólida para sostener la existencia de otras vías para el logro de los movimientos sociales. Si bien la importancia del discurso y el enmarcado se ha puesto de manifiesto en una serie de estudios, nosotros sostenemos que el significado completo que la palabra tiene para el éxito de los movimientos se capta mejor a partir del concepto de "conversación" y un examen de sus condiciones de viabilidad. La sustitución o el desplazamiento de la titularidad del poder, a pesar de ser una vía menos frecuente para el logro de los movimientos de protesta, también merece atención conceptual y empírica. En este artículo hacemos conceptualmente explícitas este conjunto de distinciones, diferenciando de manera analítica entre estos tres mecanismos de éxito de un movimiento y delineando las condiciones requeridas por cada uno de ellos para demostrarse viable y "útil". Nos basamos en extensos ejemplos extraídos de movimientos y eventos de protesta en los Estados Unidos, España y Portugal, utilizando este material empírico así como la literatura teórica existente como base para construir nuestro argumento conceptual sobre la distinción de estos tres mecanismos como tipos ideales y las condiciones que les permiten ser operativos. También planteamos la cuestión de hasta qué punto - y cuándo - los actores de movimientos pueden combinar con éxito estos mecanismos o verse forzados a seguir una u otra de estas vías hacia el logro de una forma relativamente "pura".

\section{Palabras Clave}

Discurso; Protesta; Protesta Pacífica; Protestas Antiausteridad; Resultados de los Movimientos Sociales. 
How social movements achieve the successes which can be attributed, at least in part, to their efforts is a question of paramount importance both for activists and scholars of social protest, but important work remains to be done to fully develop our understanding of the set of mechanisms that enable mobilization to induce change of some sort ${ }^{1}$. A great deal of scholarship tends to assume - and in some cases explicitly argues - that disruption is the primary mechanism through which protest movements win major concessions from the holders of power. Nonetheless, many studies and much empirical evidence provide a strong basis to argue that other paths to movement success also exist. In this paper we take up this question, and identify three quite different ways in which the encounter of movements with power-holders can generate outcomes consonant with protester objectives. We offer a clear and simple three-way typology of movement approaches to the pursuit of changes in public policy or institutional arrangements.

The theoretically distinct mechanisms that we elaborate - 'conversation', displacement and disruption - are ideal types in nature and not intended to be an exact or fully exhaustive reflection of the complete range of possibilities to be found in empirical reality. In the Weberian methodological tradition (Fishman, 2007), we view our typology as an analytical device that can help researchers -- and actors themselves - identify and understand certain coherent tendencies and logics in the ways that movements succeed in bringing about change, but we assume that the precise dynamics of success to be found in specific cases can only be uncovered through careful contextually-focused work. The three mechanisms that we elaborate are analytically quite distinct from one another but in empirical reality they can clearly be combined with one another in multiple ways by historically given actors.

In contrast to those scholarly treatments of movement success that have placed their greatest - in some cases exclusive - emphasis on the leverage provided by acts of disruption, we afford equal treatment to the three mechanisms specified above. We delineate clear differences among these avenues to success and the conditions that make it possible for protest movements to fruitfully deploy them. Our intent is to provide a theoretical lens facilitating empirical work and explanation by specifying quite different logics and practices - each with its distinctive preconditions and consequences - which can allow movements to gain tangible victories. Our effort is rooted both in a great deal of prior scholarship by others and in an in-depth case-oriented approach to studying the substance of what protesters actually do. We draw on a number of instances of social protest, most of them concentrated in the neighboring countries of Europe's Iberian Peninsula - Portu- gal and Spain. We also draw selectively from examples of movement success elsewhere - especially in the United States.

This primary focus on the Iberian Peninsula cases provides us with a large array of contentious episodes for analysis, while also offering fundamental points of contrast in the phenomena under study. The larger of the neighboring cases, Spain, has been widely recognized as a world-leader in protests of all sorts (Fishman, 2012), including not only those initiated by well-institutionalized organizations such as unions and parties but also others launched and led by 'alternative movements' (Flesher-Fominaya, 2007), such as the direct action "escraches" which have managed to partially contain the practice of housing evictions (Romanos, 2014). The smaller of the two Iberian Peninsula cases, Portugal, is generally understood to have a lower aggregate 'volume' of protest (Accornero and Ramos Pinto, 2015), yet the ability of demonstrators to influence the decisions of power-holders appears to be substantially greater than in Spain (Fishman, 2011a) and the strength of civil society organizations also appears to be more pronounced than in the larger Iberian Peninsula case (Fernandes, 2015). Thus these two national cases offer fundamental points of contrast directly relevant to our analytical concerns, even though the two countries have been historically seen as highly similar on numerous other dimensions. Portugal and Spain are remarkably unlike one another in their predominant forms of contention or 'democratic practice' and in certain crucial contextual factors that influence the social movement field (Fishman, 2011a). Moreover, these cases provide us with numerous quite specific instances of contention that shed a great deal of light on fundamental dimensions of variation in the pathways leading to movement success.

It is only by contrasting 'conversation', displacement and disruption with one another that the most decisive features of each pathway can be brought clearly into view. We recognize that specific empirical instances of movement success may be, in one way or another, more complex than this three-way typology, and may even combine features of two or three of the mechanisms that we formulate here as theoretically distinct from one another. Nonetheless, we argue that in principle, the patterns of protester/power- holder interaction that can bring about significant movement success tend to cluster together in constellations which have their distinctive logics, preconditions and consequences. For this reason, we believe the specification of these mechanisms can help to promote the study and understanding of success and failure for movements, while also contributing to the analysis of the alignment between strategies of protest and objective possibilities for their triumph. 


\section{Placing Our Analysis in Existing Work on MOVement Success}

A great deal of work has been done on movement success and the factors that make it possible. Numerous studies explicitly argue, or in some instances simply tacitly assume, that the ability of movements to bring about meaningful change rests above all on their capacity to disrupt existing institutionalized practices - thus presenting power-holders and other elites with considerable difficulties until they accede to at least some movement demands. This perspective has been strongly promoted by the important work of Piven and Cloward (1977; 1993) and by the classic pioneering contribution of Gamson (1975) on determinants of success. However, other scholars have raised questions about the tactical fruitfulness of disruption, suggesting that it may prove counter-productive (Schuman, 1972; Schumaker, 1978). Still others have pointed to a variety of other possible determinants of success located either within the movement sector (see, e.g., Morris, 1986; Staggenborg, 1991) or outside it in the external environment (McAdam, 1982; Kitschelt, 1986; Jasper and Poulsen, 1993; Giugni, 2004; Amenta, 2006). Scholars have devoted considerable attention to the effort to differentiate between types of success (Gamson, 1975; Burstein, Einwohner, and Hollander, 1995; Giugni, McAdam, and Tilly, 1998) and the determinants shaping the likelihood of their attainment (Tarrow, 1998; Giugni, 2004; Uba, 2005). Nonetheless, insufficient work has focused on the specification of mechanisms, other than disruption, that allow mobilization to generate positive change. Despite the highly influential call of McAdam, Tarrow and Tilly (2001) for scholarship centered on the elaboration of mechanisms and processes, this continues to be an area requiring new work.

In what follows we attempt to do precisely that, focusing our attention on the elaboration of mechanisms which - for reasons that we explain later - we conceptualize from the standpoint of movement actors. Our broader understanding of movements and their histories is a relational one embedded in a focus on interactions with others, but in our view it is useful to conceptualize mechanisms for success from the vantage point of movements themselves, whereas we propose to theorize the conditions which make success possible from a relational logic. To clarify this distinction between mechanisms and supporting conditions it is useful to consider an example from outside the standard concerns of social science. The mechanisms employed by firefighters to extinguish fires include the use of water delivered by fire hoses and various other approaches, but the conditions that make possible the successful use of such mechanisms are infrastructural, organizational and in many cases budgetary ones which permit firefighters to do their jobs successfully. From our perspective, mechanisms and the conditions which allow them to be usefully deployed should be analytically distinguished from one another.
Several important works have taken up the search for mechanisms underpinning social movement success. One promising line of research has attempted to integrate the literatures on non-violent methods and social movement outcomes. Gene Sharp's highly influential work, including his explication of 198 varied methods of non-violent protest in the three-volume The Politics of Nonviolent Action (1973), includes both an emphasis on the strategies that movements can adopt (v. 2) and the dynamic and processual course of social activism (v.3). More recently, scholars have built off of Sharp's early focus on nonviolent methods to an incorporation of the strategies and conditions which structure the likelihood of successful civil resistance (see, e.g., Schock 2005; Chenoweth and Stephan 2011). In contrast to the literature on civil resistance, an explicit focus on the mechanisms of social change is a rather recent trend among scholars studying social movements. ${ }^{2}$ The shift from static, and often structural, explanations of the trajectories of social contention can be traced to McAdam, Tarrow, and Tilly's (2001) pioneering work on the subject. In their highly influential Dynamics of Contention, these authors disavow general and static models, arguing strongly for the delineation of mechanisms and processes capable of constituting varied forms of social contention. McAdam, Tarrow and Tilly elucidate how mechanisms such as "brokerage" can contribute to broader polarization processes in contentious episodes as seemingly diverse as the French Revolution and the American civil rights movement. Although the "DOC" agenda has occasionally led to studies with a more explicit focus on mechanisms (see, e.g., McAdam and Su 2002; Andrews 2004; Jung, King, and Soule 2014), we turn our attention more directly to the question of how mechanisms relate to outcomes of movement success. Furthermore, in contrast to the DOC framework, we provide a greater emphasis on how the potential efficacy of the mechanisms of success is shaped by contextually-rooted historical and cultural legacies.

The most sustained and focused effort to delineate mechanisms of success is found in the valuable study of Felix Kolb (2007). In his systematic analysis of political outcomes of social mobilization, Kolb devotes considerable energy to the development of a broad five-way typology of mechanisms underpinning political change. Alongside disruption Kolb delineates "public preference, political access, judicial involvement and international politics" (2007: 73) as alternative mechanisms linking social protest to the achievement of political change. This framework, in an approach similar to that of a great deal of important work on contention, places considerable priority on institutional actors and terrains external to movements of protest. Indeed, in Kolb's framework, external institutions and structures are not simply engaged in interactions with protest; they are actually the defining element that is constitutive of sev- 
eral mechanisms affording the possibility for political change. In our view, this scholarly strategy is quite useful for predicting the probability of certain outcomes under given circumstances, but it fails to fully flesh out crucial distinctions among the avenues of practice taken up by movement actors themselves. The analytical focus of Kolb's mechanisms centers largely on the external institutional environment - an arena that we look to in order to delineate conditions favorable to the deployment of the mechanisms we elaborate. Our aim is quite different: As noted above, we seek to specify crucial analytic differences between forms of practice adopted by movements in their search for success.

Thus, despite the many advantages of applying a relational approach to the study of movements ${ }^{3}$ - or other significant social phenomena -we find it useful, in conceptualizing mechanisms of success, to center our primary analytic vision on movements themselves and on the type of protest-practice they deploy rather than allowing institutional responses to protest to serve as a constitutive component of the mechanisms elaborated. In approaching our subject matter this way, we do not mean to place in question the predictive usefulness of examining external constraints and incentives as crucial determinants of success. Our focus in this paper is intended to complement such approaches by generating analytical insights geared toward the perspectives, aspirations and challenges of those engaged in the effort to promote change through social mobilization. Our objective is a rather specific one oriented toward the pursuit of knowledge that is meaningful for movement actors and the scholars who study them.

For each of the three mechanisms presented here, we focus initially on a paradigmatic case in order to draw clearly into focus central features of the 'type'. We seek also to identify other instances of mobilization in which success was achieved through the same mechanism and then to specify conditions that appear to be more or less required for this avenue of success to be open, and additionally to delineate distinctive consequences or 'shapes of success' attributable to the mechanism in question.

\section{‘Conversation’ as an Avenue to Success}

In September 2012, social movements in Portugal organized nationwide protests against the latest turn in austerity policies pushed on their country by the 'troika' of the European Central Bank, the International Monetary Fund and the European Commission - together, the executive administrators of the country's controversial 2011 'bailout' (Fishman, 2011b). The center-right government elected in June 2011, in elections brought on by the bailout crisis (Magalhaes, 2012), had recently announced plans to reduce the country's fiscal deficit by introducing an across the board increase in the payroll tax de- ducted from the paychecks of employees thus, in effect, cutting pay for all wage and salary earners. Anti-austerity social movements quickly mobilized widespread public indignation which coalesced in a large demonstration held in late September outside the Presidential Palace in Lisbon where chief of state Anibal Cavaco Silva had called a meeting of the advisory Conselho de Estado to review the policy plans of Prime Minister Pedro Passos Coelho. According to widespread accounts in the country's news media, the chants of demonstrators - among them "Cavaco, listen, the people are strugglin' (Cavaco, escuta, o povo esta em luta)" - were clearly audible inside the chambers where the meeting of state took place. Remarkably, President Cavaco Silva, the first center-right politician to win election to the chief of state position in the three-plus decades following the country's 1974 democratic revolution, remarked that "we cannot fail to hear the country", while the Prime Minister who had proposed the across the board payroll tax increase declared that "we are not deaf or blind with regard to the country". The government withdrew its proposal and began to search for alternative, less onerous, ways to pursue its budgetary objectives. ${ }^{4}$ Demonstrators asked to be heard and they were.

This is far from the only case in which Portugal's elected officials have shown an inclination to listen to the voices of discontent articulated in the streets outside the halls of power. Indeed the country's political history, following its social revolutionary pathway to democracy in the 1970s, is replete with examples of such conduct by demonstrators and power-holders (Fishman, 2011a). In January 2006, only days after the election of Cavaco Silva to the country's presidency, a group of poor and mostly African-origin immigrants were evicted from formally illegal dwellings slated for demolition. Those evicted and their supporters took actions extending well beyond their initial resistance to the evictions; they began a broadly focused campaign in favor of "the right to housing" which brought their voices before the national public, thanks to coverage in the news media, and into dialogue with members of all parties present in the country's parliament. The immigrants waged a campaign of demonstrations and resistance but their principal efforts centered on the use of their voices in the effort to reach a wide audience - including institutional power-holders. Housing protesters, like anti-austerity activists, sought and achieved a hearing. In the Portuguese context, the voices of discontent proved a stronger instrument for success than their disruptive capacities; their 'conversation' with the holders of institutionalized power contributed in crucial ways to their ability to win victories such as the government's withdrawal of plans to raise the payroll tax and earlier concessions on issues related to housing and other matters (Fishman, 2011a). 
We argue that episodes of contention such as these offer evidence of a crucial mechanism connecting social movement efforts to successful outcomes, one that holds relevance well beyond the borders of Portugal. By 'conversation' we understand not only formal episodes of face to face dialogue or the use of institutionalized channels for regular consultation, but more broadly any instance of contention in which the voices of discontent carry more weight than the physically disruptive acts of protesters in securing a change in the direction of public policy. 'Conversation' in our sense may include actual discussions between activists and power-holders but may also be understood to incorporate any exchange of perspectives through the public declarations and discourse of protesters and institutional office holders who never actually talk to one another in direct face to face fashion. Although the importance of discourse and framing has been highlighted in numerous scholarly works on social protest, we argue that the full contribution of talk itself to movement success is best captured through this concept of "conversation" and an examination of the preconditions for its viability. Some scholars have disaggregated what we understand as conversation - differentiating for example between attempts at persuasion and mere attempts to bargain (Andrews, 2004) or Lakey's (1968) earlier distinction between conversion and persuasion. However, to the extent that such efforts involve the use of voice and the interchange of perspectives with others, we see the overarching unity of attempts at conversation as meriting cohesive treatment in the fashion proposed here. Conversation by its very nature involves talking, listening and interchanging with others. We contend that many historically significant triumphs of social movements owe at least as much to 'conversation' as to disruption, but an adequate understanding of this pathway to success, and all others, requires a careful delineation of its requisites.

We identify two fundamental preconditions for conversation, both of them rooted in the cultural and cognitive frameworks of actors. In order to fruitfully engage in 'conversation' activists clearly require the capacity to articulate their grievances and objectives in a fashion that attracts the interest and comprehension of their desired audiences or conversational partners (Snow and Benford, 1988). The conversational force and reach of their claims may be a function, in part, of their 'discursive horizons' which, in turn, are significantly conditioned by their social ties and interactional histories (Fishman, 2004). In a very real sense, the ability of movement activists to attain victories through their 'conversation' rests in part on their cultural capacities. Whereas some activists are able to construct compelling narratives (Polletta, 2006) or articulate broadly engaging analyses of the phenomena responsible for their discontents, others can do little more than identify their most immediate and narrow grievances, thus restricting their efforts to mere defensive localism (Fishman, 2004), a poor basis for initiating genuine 'conversation'. But discursive capacity is only one side of the cultural basis for successful 'conversation'. Clearly if social mobilization is to achieve victories through the words and voices of protesters, it is essential that someone who 'matters' for the attainment of success is actually listening. The culturally-rooted tendency of power holders to listen to voices of protest - or, alternatively, to deny their relevance or legitimacy - stands as a fundamental determinant of the possibilities for movement success through 'conversation'.

The relative openness of Portuguese power-holders to the voices of social discontent emerged as a socio-historical consequence of the country's unusual pathway to democracy through social revolution in the 1970s (Fishman, 2011a). However, the historically-rooted understanding of routine politics that conditions the response of Spanish power-holders to the voices of discontent that abound in that country's post-Franco political system has been thoroughly unlike that found across the border in Portugal (Fishman, 2012). Indeed, in Spain, power-holders have often not only simply evidenced a disinterest in hearing the voices of discontent; they have actually questioned their legitimacy and thus their rightful place in democratic public life. The inclination of many authorities to delegitimize and marginalize the voices of protesters was recently exemplified by declarations of the police chief of Valencia, Spain's third largest city, who in February 2012 openly referred to student protesters as "the enemy". ${ }^{5}$ Elected officials, not only in the country's main conservative party - the Partido Popular (PP) - but also in some instances within the Socialist Party (PSOE), have often treated the voices of protest as a problem of (dis)order rather than a welcome component of democratic public life (Fishman, 2012). In this cultural climate, characterized by rather restrictive dominant assumptions about the normal contours of political life, it is quite difficult for protesters to engage in effective 'conversation' outside those micro-contextual settings in which subcultural understandings and practices more favorable to the political incorporation of protest are to be found (Fishman, 2004). Contextual factors, many of them cultural in nature and rooted in historical experiences, strongly condition the viability of 'conversation'.

In a given setting in which predominant understandings of the contours of political life tend to be exclusionary, even social mobilizations that initially seem to offer the hope of initiating 'conversation' can easily fail to do so, and may end up evolving into episodes of disruption. The formal existence of the right to protest in a democratic constitution is no guarantee that elected representatives will treat protesters as fully legitimate political actors. In the Spanish case, demonstrations outside - or in the vicinity of - 
parliament chambers at the national or regional level have often ended in confrontations between protesters and the police instead of discussions between activists and elected officials ${ }^{6}$. The cultural assumptions shaping the boundaries of routine political life the 'polity' in the language used by many theorists of contention (Tilly 1978) - can render quite unlikely the sort of mutual recognition needed for 'conversation' to prosper, and as a result protestors are more likely to engage in disruptive practices in such settings. Yet it would be a serious mistake to treat such cultural constraints as an unchanging and permanently immovable obstacle to 'conversation'.

As a number of theorists of contention have persuasively argued, social protest is at times able to redefine cultural assumptions about politics and the boundaries of inclusion in routine political life (Tarrow, 1993; Clemens, 1998; Gamson, 1998; della Porta, 1999). In della Porta's very useful formulation, "during protest cycles, public order and protest rights become, in fact, the most relevant issues in the symbolic struggle between social movements and their opponents" (1999: 68). This was clearly the case during the great 1960s wave of mobilization in the United States when 'conversation' was both a tactic deployed and an objective pursued by the civil rights movement and other collective actors. When, at least for large segments of the population, movements succeed in redefining cultural assumptions about 'polity membership', they may open up opportunities for 'conversation' initiated from within their own ranks and from other movements as well. Discussions in the United States between Martin Luther King and prominent elected officials from the White House downward (Garrow, 1978: 35-36; Stern, 1992: 25 ) offer only one example of this broader pattern. But 'conversation' was not always available as an option for American social protesters and is often not credible, even for those individually predisposed in principle toward this instrument of protest. Whether they are created by protest waves, or historically inherited from the struggles of earlier generations, the cultural assumptions and capacities required for "conversation' to be fruitfully deployed seem to be a strong requisite for this mechanism to be successful.

Whether 'conversation' is seen as a most desired approach or merely as a weak substitute for more militant tactics and aspirations is a question on which movements and activists have been historically divided. After all, the pursuit of 'conversation' by activists implies some degree of acceptance of existing power structures and authorities, a concession that particularly radical movements have been reluctant to make. From the standpoint of the most 'maximalist' aspirations of some movements, the only fully satisfying pathway to success would appear to be displacement, but to what degree and under what circumstances is this avenue genuinely open and available? This is the question to which we now turn.

\section{Displacement: The ‘Gold Standard’ of MOVEMENT Success?}

A small town in predominantly agricultural southern Spain has become something of a 'magnet' for political journalists, activists and social scientists searching for alternatives to the frequently grim realities of the global neo-liberal era ${ }^{7}$. In the municipality of Marinaleda ${ }^{8}$ a combination of social mobilizations and local policies enacted by the elected town government have made possible a wide range of collective solutions to the economic challenges faced by townspeople. The town's mayor, Juan Manuel Sánchez Gordillo, a union and political leader situated to the left of the country's major political parties, has led agricultural workers in a series of land occupations that began during Spain's postFranco political transition. The earliest of these efforts to occupy large landed estates was short lived and largely symbolic in its effects, but beginning in the 1980s the length of the land occupations carried out by Marinaleda farmworkers increased considerably. Sánchez Gordillo won election as the town's mayor soon after the democratic transition and has remained in that position, regularly winning reelection, while also leading local residents in a tireless series of campaigns. Townspeople and their supporters have engaged not only in the occupation of nearby agricultural estates but also in building occupations and other publicly visible actions in the nearby city of Seville, the capital of Andalusia.

The movement led by Sánchez Gordillo has adeptly combined numerous forms of pressure and contention with the levers of local power provided by its control over the Marinaleda city hall. Movement activists have engaged in 'conversation' with regional and national governmental authorities in the moderate Socialist Party (PSOE), but have never allowed their discussions with power-holders to diminish the militant edge of their tactics and strategies. They ultimately won operating control over a large estate located at the edge of town and secured materials and facilities from the Andalusian regional government for other town projects such as the collective construction of affordable dwellings for town residents. They founded local cooperatives engaged in the canning and sale of vegetables raised in the occupied estate and in the resolution of the housing needs of the Marinaledans. In their construction of a sort of 'socialism in one town', activists and their charismatic leader managed to effectively displace a range of institutions and structures that previously governed the welfare of residents and that continue to do so in otherwise similar towns in the region. In their place, the residents of Marinaleda created new collective institutions and practices which they controlled. Their displacement of conventional capitalistic structures and institutions gave way to widespread changes in the living and working conditions of town residents. The displacement mechanism was successfully deployed in this case with great difficulty and in an unusual context - an especially militant small town in a region in which public opinion and 
government authorities were both situated well to the left of Spain's nationwide median point. Without this combination of a strongly committed, well-organized and militant core of activists in the town itself and the relatively favorable regional context afforded by the center-left Andalusian government of the PSOE, the effort to displace existing ownership structures and other conventional institutions could not have succeeded. Although the requisites for successful displacement are not commonly in existence, the range of objectives that can potentially be attained by this pathway is so broad and deep that it easily captures the attention of numerous observers and activists. The odds of reproducing such experiences are very low but the magnitude of the rewards involved is great enough to command the interest of a large public.

Displacement obviously also takes place at the national level in instances of revolution but the conditions making such an outcome possible are rarely found especially in democratic polities with functioning bureaucratic states (Skocpol, 1979; Goodwin, 2001). In the historically unusual contexts in which revolutions successfully take place, displacement is, to one degree or another, practiced. Social subordinates and organized movements seeking to change existing arrangements have real opportunities in such settings to replace the structures and institutions they oppose instead of simply pressing for their reform. The maximalist aspirations of movements are realized when contextual factors that create an opening align positively with movement capacities, making displacement possible. Thus this mechanism contributes highly visible but quite unusual exceptions to the more commonly available pathways to movement success.

Given that displacement seems to be possible only in exceptional contexts or issue domains and that 'conversation' appears to be a rather difficult avenue to pursue in Spain, one might be tempted to conclude that social movement victories of any sort are quite unlikely in this country. Such a conclusion would be thoroughly unwarranted. Social protest has not only been extremely common in post-Franco Spain, it has also often led to the attainment of significant objectives aspired to by activists. The record of Spanish protest movements offers much evidence in support of scholarly claims on the usefulness of disruption, the theme to which we now turn.

\section{Disruption: A Well-Recognized Avenue to SUCCESS}

In January 2014, when the municipal government of Burgos-a provincial capital in conservative northern Castile - launched an expensive and cumbersome plan to redesign streets ${ }^{9}$ and public spaces of a working-class neighborhood known as "Gamonal", their infrastructural plan led to massive social protest. ${ }^{10}$ Residents of the neighborhood responded to the redesign proposed by the municipal government of the right-wing Partido Popular (PP) with indignation over the projected large expenditure of funds on urban spatial reconfiguration while pressing social needs remained unaddressed due to austerity-era cutbacks. Large peaceful demonstrations and assemblies of disaffected residents manifested the widespread neighborhood opposition to the project, but it was ultimately smaller scale incidents of violent collective action and the confrontations of militant protesters with the police that captured nationwide attention throughout Spain. The most militant protesters set fire to garbage containers and other items located in the streets, stoned bank offices and attacked the materials slated for use in the urban redesign project. The police employed forceful tactics in response and made numerous arrests. For several days and nights an urban conflict featuring both fires and confrontations in the streets served to remind Spaniards that public dissatisfaction over austerity-induced cutbacks and the economic crisis could easily explode into street violence.

Municipal authorities initially sought to delegitimize the protests and to reaffirm their plan for urban redesign but their inability to contain or end the conflict ultimately led to an abrupt change in plans. The municipal government ultimately withdrew its redesign project, cancelling the plan to reconfigure Gamonal. Neither 'conversation' nor displacement was readily available to working-class residents of this Burgos neighborhood. Yet their collective actions ultimately attained the objective which motivated their protests. Disruption, much of it rooted in small-scale violent tactics in the streets, was the only available avenue of success for residents of Gamonal and they - or at least some among them - used it effectively.

The experience of this neighborhood in a provincial capital located in a generally conservative region of the country is emblematic of broader tendencies and patterns of contention in Spain. Numerous disaffected Spaniards from miners in Asturias to auto workers in the Andalusian town of Linares threatened with the loss of their jobs and 'okupas' engaged in building occupations have made use of disruptive tactics to press their claims on public authorities. Street and railway line blockages, barricades in the streets and attacks on bank offices or other corporate targets are only some of the disruptive tactics included in the standard repertoires of contention of militant Spanish protesters. Their actions, along with far larger peaceful protests, have formed a defining feature of collective life in Spain's post-Franco democracy and have met with a wide range of responses from incumbent authorities. A complex set of historical experiences helps to explain this pattern (Fishman, 2012).

The conditions that have made success through disruption viable in some Spanish episodes of contention have some elements in common - and some points of differentiation with - the conditions making displacement possible in unusual instances. Where disruption has triumphed, as in Gamonal, clearly the 
costs of repression exceed the costs of acquiescence for power-holders - at least episodically and temporarily. In contrast, where displacement proved to be possible, the costs of repression exceeded the costs of acquiescence on a more sustained and ongoing basis. And whereas successful displacement required a considerable organizational infrastructure on the part of the farmworkers of Marinaleda - supplemented obviously by their creative use of elective municipal institutions - triumph through disruption can be achieved with relatively weak organizational resources on the part of protesters, a common state of affairs in Spain.

While the rather constricted and exclusionary bounds of the Spanish polity, at least as it has been understood by many mainline political actors, often encourage the adoption of a disruptive approach by protesters, the effectiveness of disruption, at least under certain conditions, has been evident even in national contexts where opportunities for 'conversation' may be more widespread. As noted above, not only do such opportunities vary by context, so too does the cultural capacity "to be heard." Moreover, the ability to gain leverage through 'conversation' is usually stratified across sub-groups within unequal societies. In short, who power-holders are willing to listen to is often structured not only by cultural legacies of past contention and the cultural capacity of the protesters' discourse, but also by the unequal distribution of power and resources within a society.

In contexts where the balance of power and resources is skewed heavily in favor of power-holders, certain sub-groups within society may pursue disruption as their only viable route to effect change (Piven and Cloward, 1977). Such is the case with the confrontational activism of the American Indian Movement (AIM) in the United States. Through a series of disruptive episodes in the early 1970s, including the takeover and destruction of the Bureau of Indian Affairs (BIA) headquarters and the armed occupation of Wounded Knee, South Dakota, AIM forced the social, cultural, and economic plight of America's long-forgotten indigenous populations into the consciousness of political elites and the general public alike ${ }^{11}$. Though no doubt aided by the efforts of less militant indigenous rights organizations (Cobb and Fowler, 2007), AIM's disruption provided a vital impetus to the push for indigenous self-determination during the Nixon administration and beyond.

\section{Combining and Differentiating these Mechanisms: A Complex Challenge}

Activists often face the complex challenge of seeking to pragmatically combine in productive ways the three mechanisms discussed here- or of differentiating among them in clear ways to gain legitimacy or leverage of some other sort. Whether and how it is possible to combine the three mechanisms - or logics of contention - is a vexing question both for activists and those who study them. The episodes of conten- tion discussed in this paper, as well as countless others, certainly include cases in which movements have attempted to play multiple cards either simultaneously or sequentially - pressing authorities in disruptive ways while also speaking to them when possible, searching for ways to displace existing structures and institutions while also pursuing concrete concessions from incumbent authorities, articulating grievances in the hope of being heard while also applying pressure in other ways, and so forth. Yet the logics informing the three mechanisms really are quite different ones in principle and the use of any one of these logics or mechanisms can, under certain circumstances, interfere with the others. Disruption may on occasion undercut the willingness of authorities or mass publics to listen to the voices of discontent, and 'conversation' may dissipate the militant resolve needed to triumph in a campaign of disruption or one that aims at displacement. Activists face a real tension between the temptation to pragmatically combine elements of two or even all three mechanisms and the 'purist' inclination to emphasize just one of them, thereby avoiding the risk of "contaminating" its logic by such combinatory tactics.

This challenge - the one faced by activists - is obviously mirrored by the task faced by scholars attempting to make sense out of such choices. We argue that the analytical distinction between these three avenues to success is a useful instrument in making sense of such challenges. Only by fully understanding the distinct logics and processes that activists may attempt to combine or keep separate is it possible to gain explanatory leverage and understanding on the challenges faced by movements in their pursuit of success. The elaboration of mechanisms of success as seen from the vantage point of movement actors can contribute in useful ways to the broader goals of social movement scholarship.

\section{AcKNowledgments}

For extremely useful feedback on an earlier version, we wish to thank participants in the 2015 Midterm Conference of the ESA RN25 (European Sociological Association's research network on social movements) on, "From Contention to Social Change: Rethinking the Consequences of Social Movements and Cycles of Protest" as well as participants in the SPAM workshop at the University of Notre Dame and both the special issue editors and the anonymous readers. Also, Fishman gratefully acknowledges funding support received through the CONEX program from the Universidad Carlos III de Madrid, the European Union's Seventh Framework Program for research, technological development and demonstration under grant agreement number 600371, Spain's Ministerio de Economía y Competitividad (COFUND2013-40258), and the Banco de Santander. Fishman also acknowledges support by the Spanish Ministry of Economy and Competitiveness (grant number CSO2013-41035-P). 


\section{Notes}

1. We focus here on changes in public policies or institutional arrangements of concern to the movements in question.

2. For a discussion of how the literatures on social movements and civil resistance have traditionally diverged, and suggestions for their convergence, see Schock (2013).

3. Our own work is often relational both in the design of research questions and the theoretical framing of our findings (Fishman, 2004; 2009), but in our view despite the usefulness of that approach, for certain purposes it remains important to examine social dynamics from a perspective centred on one party to an interaction.

4. We have relied on extensive coverage in the Portuguese press, consulted online including the Portuguese Publico, Sic Noticias and Diario de Noticias.

5. See El Pais, internet edition, February 20, 2012, accessed February 21, 2012.

6. Demonstrations aimed at taking grievances to the steps of parliamentary chambers have led to confrontations with police rather than dialogue in Madrid and in Spain's regions - for example in Catalunya in June 2011 and in

\section{BiBLIOGRAPHY}

Accornero, G. and P. Ramos Pinto. 2015. "'Mild Mannered'? Protest and Mobilisation in Portugal under Austerity, 2010-2013". West European Politics 38(3): 491-515. http://dx.doi.org/10.1080/01402382.2014.937587

Amenta, E. 2006. When Movements Matter: The Townsend Plan and the Rise of Social Security. Princeton, NJ: Princeton University Press.

Andrews, K. T. 2004. Freedom is a Constant Struggle: The Mississippi Civil Rights Movement and its Legacy. Chicago: University of Chicago Press.

Burstein, P., R. L. Einwohner, and J. A. Hollander. 1995. "The Success of Political Movements: A Bargaining Perspective." Pp. 275-295 in The Politics of Social Protest: Comparative Perspectives on States and Social Movements, edited by J. Craig Jenkins and Bert Klandermans. Minneapolis: University of Minnesota Press.

Chenoweth, E., and M. J. Stephan. 2011. Why Civil Resistance Works: The Strategic Logic of Nonviolent Conflict. New York: Columbia University Press.

Clemens, E. S. 1998. "To Move Mountains: Collective Action and the Possibility of Institutional Change." Pp. 109123 in From Contention to Democracy, edited by Marco G. Giugni, Doug McAdam, and Charles Tilly. Lanham, MD: Rowman \& Littlefield.

Cobb, D. M., and L. Fowler, eds. 2007. Beyond Red Power: American Indian Politics and Activism Since 1900 Santa Fe: School for Advanced Research Press.

della Porta, D. 1999. "Protest, Protesters and Protest Policing," Pp. 66-96 in How Social Movements Matter, edited by M. Giugni, D. McAdam, and C. Tilly. Minneapolis: University of Minnesota Press.

Fernandes, T. 2015. "Rethinking Pathways to Democracy: Civil Society in Portugal and Spain, 1960s - 2000s" Democratization, 22(6): 1074-1104. http://dx.doi.org/10.1080/ 13510347.2014 .901966

Fishman, R. M. 2004. Democracy's Voices: Social Ties and the Quality of Public Life in Spain. Cornell: Cornell University Press.
Galicia in March 2014. Dynamics of contention turned what initially appeared to be an opportunity for 'conversation' into episodes of disruptive confrontation.

7. For an outstanding collection of work on social responses to the neo-liberal era, see Hall and Lamont (2013)

8. This section is largely based on our interview with Sanchez Gordillo and visit to Marinaleda on May 8, 2012.

9. The centerpiece of the plan was the project of creating a "bulevar", which is to say a street with a pedestrian median where a more conventional street now runs.

10. We have relied on extensive coverage in the Spanish press including El Pais and Publico, as well as broadcast reports on the events in Gamonal.

11. While the majority of the American public reacted with sympathy to AIM, Everson's dissertation research shows how dominant group bystanders also refashioned cultural narratives surrounding American Indians in order to more effectively suppress the movement's social change efforts, particularly in the geographic locations where the threat from 'Red Power' was perceived to be most severe.

Fishman, R. M. 2007. “On Being a Weberian (after Spain's 11 - 14 March): Notes on the Continuing Relevance of the Methodological Perspective Proposed by Weber" Pp. 261- 289 in Max Weber's "Objectivity" Reconsidered, edited by L. McFalls, Toronto: University of Toronto Press.

Fishman, R. M. 2009. "On the Costs of Conceptualizing Social Ties as Social Capital," Ch. 3 in Social Capital: Multidisciplinary Perspectives, edited by V. Bartkus and J. Davis, Edward Elger Press. http://dx.doi. org/10.4337/9781848445963.00012

Fishman, R. M. 2011a. "Democratic Practice after the Revolution: The Case of Portugal and Beyond" Politics \& Society, 39(2): 233-267. http://dx.doi. org/10.1177/0032329211405439

Fishman, R. M. 2011b. "Portugal's Unnecessary Bailout," New York Times, April 12, 2011.

Fishman, R. M. 2012. "On the Significance of Public Protest in Spanish Democracy," Pp. 351-366 in Democracia, Politica i Societat: Homenatge a Rosa Viros, edited by J. Jordana, V. Navarro, F. Pallares and F. Requejo. Universitat Pompeu Fabra and Avenç.

Flesher-Fominaya, C. 2007. "Autonomous Movements and the Institutional Left: Two Approaches in Tension in Madrid's anti-Globalization Network." South European Society \& Politics 12(3): 335-358. http://dx.doi. org/10.1080/13608740701495202

Gamson, W. A. 1975. The Strategy of Social Protest. Homewood, II: Dorsey.

Gamson, W. A. 1998. "Social Movements and Cultural Change," Pp. 57-77 in From Contention to Democracy, edited by M. G. Giugni, D. McAdam, and C. Tilly, Lanham, MD: Rowman \& Littlefield.

Garrow, D. J. 1978. Protest at Selma: Martin Luther King, Jr., and the Voting Rights Act of 1965. New Haven, CT: Yale University Press.

Giugni, M. 2004. Social Protest and Policy Change: Ecology, Antinuclear, and Peace Movements in Comparative Perspective. Lanham, MD: Rowman \& Littlefield. 
Giugni, M., D. McAdam, and C. Tilly. 1998. From Contention to Democracy. Lanham, MD: Rowman \& Littlefield.

Goodwin, J. 2001. No Other Way Out. New York: Cambridge University Press. http://dx.doi.org/10.1017/ CBO9780511812125

Hall, P. A., and M. Lamont, eds. 2013. Social Resilience in the Neoliberal Era. Cambridge: Cambridge University Press.

Jasper, J. M., and J. Poulsen. 1993. "Fighting Back: Vulnerabilities, Blunders, and Counter-mobilization by the Targets in Three Animal Rights Campaigns." Sociological Forum 8(4): 639-657. http://dx.doi.org/10.1007/BF01115215

Jung, W., B. G. King, and S. A. Soule. 2014. "Issue Bricolage: Explaining the Configuration of the Social Movement Sector, 1960-1995." American Journal of Sociology 120(1): 187-225. http://dx.doi.org/10.1086/677196

Kitschelt, H. 1986. "Political Opportunity Structures and Political Protest: Anti-Nuclear Movements in Four Democracies." British Journal of Political Science 16: 57-85. http://dx.doi.org/10.1017/S000712340000380X

Kolb, F. 2007. Protest and Opportunities: The Political Outcomes of Social Movements. Frankfurt: Campus Verlag.

Lakey, G. 1968. The Sociological Mechanisms of Non-Violent Action. Oakville, Ont.: Canadian Peace Research Institute.

Magalhaes, P. C. 2012. "After the Bailout: Responsibility, Poli$\mathrm{cy}$, and Valence in the Portuguese Legislative Election of June 2011." South European Society and Politics 17(2): 309-327. http://dx.doi.org/10.1080/13608746.2 012.701410

McAdam, D. 1982. Political Process and the Development of Black Insurgency, 1930-1970. Chicago: University of Chicago Press.

McAdam, D., and Y. Su. 2002. "The War at Home: Antiwar Protests and Congressional Voting, 1965 to 1973." American Sociological Review 67(5): 696-721. http://dx.doi. org/10.2307/3088914

McAdam, D., S. G. Tarrow, and C. Tilly. 2001. Dynamics of Contention. Cambridge: Cambridge University Press. http://dx.doi.org/10.1017/CBO9780511805431

Morris, A. D. 1986. Origins of the Civil Rights Movement. New York: The Free Press.

Piven, F. F., and R. Cloward. 1977. Poor Peoples' Movements: Why They Succeed, How They Fail. New York: Vintage Books.

Piven, F. F., and R. Cloward. 1993. Regulating the Poor: The Functions of Public Welfare. 2nd ed. New York: Vintage.

DAVID W. EVERSON is a PhD candidate in sociology at the University of Notre Dame in South Bend, Indiana. His research focuses on American Indian rights, social movements, and Native-white relations in the United States. He is currently finishing a dissertation project on how geographic proximity to protest shapes the evolution of dominant cultural narratives of social movements through a qualitative longitudinal investigation into Euro-American memory of, and attitudes toward, the American Indian Movement (AIM) and American Indians from 1973 to 2015.

ROBERT M. FISHMAN, CONEX-Marie Curie Professor of Political Science and Sociology at the Universidad Carlos III (Madrid), previously taught at the University of Notre Dame and
Polletta, F. 2006. It Was Like a Fever: Storytelling in Protest and Politics. Chicago: University of Chicago Press. http:// dx.doi.org/10.7208/chicago/9780226673776.001.0001

Romanos, E. 2014. "Evictions, Petitions, and Escraches: Contentious Housing in Austerity Spain." Social Movement Studies 13(2): 296-302. http://dx.doi.org/10.1080/1474 2837.2013.830567

Schock, K. 2005. Unarmed Insurrections: People Power Movements in Nondemocracies. Minneapolis: University of Minnesota Press.

Schock, K. 2013. "The Practice and Study of Civil Resistance." Journal of Peace Research 50(3): 277-290. http:// dx.doi.org/10.1177/0022343313476530

Schumaker, P. D. 1978. "The Scope of Political Conflict and the Effectiveness of Constraints in Contemporary Urban Protest." Sociological Quarterly 19: 168-184.

Schuman, H. 1972. "Two Sources of Antiwar Sentiment in America." American Journal of Sociology 78(3): 513536. http://dx.doi.org/10.1086/225362

Sharp, G. 1973. The Politics of Nonviolent Action, 3 volumes. Boston: Porter Sargent.

Skocpol, T. 1979. States and Social Revolutions: A Comparative Analysis of France, Russia, and China. Cambridge: Cambridge University Press. http://dx.doi.org/10.1017/ CBO9780511815805

Snow, D. A., and R. D. Benford. 1988. "Ideology, Frame Resonance, and Participant Mobilization." International Social Movement Research 1(1): 197-217.

Staggenborg, S. 1991. The Pro-Choice Movement: Organization and Activism in the Abortion Conflict. Oxford: Oxford University Press.

Stern, M. 1992. Calculating Visions: Kennedy, Johnson, and Civil Rights. New Brunswick, NJ: Rutgers University Press.

Tarrow, S. 1993. "Social Protest and Policy Reform: May 1968 and the Loi d'Orientation." Comparative Political Studies 25(4): 579-607. http://dx.doi. org/10.1177/0010414093025004006

Tarrow, S. 1998. Power in Movement: Social Movements, Collective Action and Politics. 2nd ed. New York: Cambridge University Press. http://dx.doi.org/10.1017/ CBO9780511813245

Tilly, C. 1978. From Mobilization to Revolution. Reading, MA: Addison-Wesley.

Uba, K. 2005. "Political Protest and Policy Change: The Direct Impacts of Indian anti- Privatization Mobilizations, 1990-2003." Mobilization 10(3): 383-396.

at Harvard University. He works on interconnections between politics and culture, inequality and political inclusion, social movements and democracy - adopting a historical approach to the analysis of these themes. His articles have appeared in the American Sociological Review, World Politics, Annual Review of Political Science, Politics and Society, the Revista Española de Investigaciones Sociológicas, the Journal for the Scientific Study of Religion, Comparative Politics, Studies in Comparative International Development and other scholarly journals as well as the New York Times and other newspapers. Fishman's books include Democracy's Voices (2004), winner in 2005 of Honorable Mention for Best Book from the American Sociological Association's Section on Political Sociology. He is currently writing a book on Democratic Practice: Origins of the Iberian Divide in Political Inclusion. 